INT’L. J. AGING AND HUMAN DEVELOPMENT, Vol. 59(4) 391-420, 2004

\title{
SPIRITUAL TURNING POINTS AND PERCEIVED CONTROL OVER THE LIFE COURSE
}

\author{
KATHERINE L. FIORI \\ University of Michigan \\ JUDITH C. HAYS \\ KEITH G. MEADOR
}

Duke University

\begin{abstract}
Recent evidence indicates that spirituality and religion are associated with both physical and psychological health. Because a belief that rewards are largely determined by external forces tends to be detrimental to mental health, the idea that God can be equated with such an external force seems contradictory to the proven benefits of religion and spirituality. The purpose of this article is to examine changes in perceived control in the context of spiritual turning points as uncovered in the narrative histories of 30 elderly people. We propose that for many people who derive benefits from religion or spirituality, God may act as a mediator, in the sense that trusting in God provides personal control. In addition to creating a model of God-mediated control, the study's findings suggest a relationship between recall for type of control during a spiritual turning point and the interpretation of that turning point in late life.
\end{abstract}

Recent evidence indicates that spirituality and religion are associated with both physical and psychological health. From a physiological perspective, religion may actually decrease the risk of death after surgery (Oxman, Freeman, \& Marnheimer, 1995) and act as a protective factor against high blood pressure and hypertension (Levin \& Vanderpool, 1989). Religion appears to have positive effects on functional status, as well (Idler \& Kasl, 1997). Furthermore, religion 
may help increase the lifespan and decrease mortality rates (Koenig et al., 1999). From a psychological perspective, strong religious faith may cause negative life events to be seen as opportunities for spiritual growth (Ellison, 1991). Religion and/or spirituality may act as a stress buffer (McFadden, 1995). For example, prayer can act as a relaxation response, or stress can be buffered by the enjoyment of attending services, the presence of clergy and a religious social support group, the encouragement of health-related behaviors, and a way of seeing the world as meaningful (Idler \& George, 1998; Wallis, 1996). Furthermore, religion and/or spirituality can aid in problem-solving (Pargament et al., 1988) and can protect against depression (Idler \& Kasl, 1992).

However, not all studies have shown that religion is beneficial. In fact, religion has also been shown to have quite the opposite effect. Negative effects are often linked to the ways in which people view their relationship to God and how spirituality or religion is used as a coping resource. According to Dein and Stygal (1997), religion can help or hinder an individual's mental health depending on the individual's attributions. They hypothesized that patients coping with chronic illness, for instance, might become angry with God and worsen their psychological health. Using a deferral-to-God problem-solving strategy can also be an unhealthy by-product of religion (Seybold \& Hill, 2001). Pargament and Brant (1998) describe other harmful forms of religious coping, such as reframing a religious event in terms of a punishment from God. Finally, some specific religious beliefs might actually become manifested in psychopathologies in times of stress or illness (e.g., the expectations of obedience in the Mormon religion may lead to inappropriate guilt or even obsessive-compulsiveness; Barlow \& Bergin, 1998).

Thus, different religious interpretations have different outcomes for psychological health (Pargament \& Hahn, 1986). One way in which people's religious interpretations vary may stem from differing loci of control. Research on attribution theory by psychologists of religion offers some insight into the relationship among religious interpretations (attributions), sense of control, and well-being. Attribution theories assume that people seek to make sense of their experiences (Spilka, Shaver, \& Kirkpatrick, 1985). Bulman and Wortman's (1977) classic study illustrates well the importance of assigning meaning to an event. In this study, accident victims' success in coping was dependent on their attributions and explanations of the accidents. In a similar study, McIntosh, Silver, and Wortman (1993) found that "importance of religion" to individuals suffering from the loss of a child was positively related to cognitive processing and finding meaning in the death. According to Spilka (1985), people not only make attributions because of a general desire to seek meaning in the world but also to attempt to control and predict events and to maintain and/or enhance self-esteem. These authors claim that the particular attribution selected on a given occasion depends on its ability to restore these three variables (i.e., meaning-seeking, control, self-esteem) to satisfactory levels. Furthermore, depending on its salience to an individual, religion can offer this satisfaction. Most importantly for this article are the ways 
in which religion can satisfy the need or desire to predict and control events. According to these authors, religion offers extrinsic control, such as prayer and the execution of prescribed rituals, as well as a more intrinsic form of control due to the belief that if one trusts in God and has faith, then things will turn out well.

Miner and McKnight (1999) examined religious attributions and found that they have important direct and indirect effects on positive religious coping in health situations. Contrary to the researchers' hypotheses, they found that a sample of Presbyterians did not assert God's direct control over life events; instead, the respondents reported a variety of religious and secular attributions that suggested an interaction between divine and human causes. Such attributions might be quite healthy in the sense that some personal control is maintained in spite of (or because of) an individual's relationship with God. Similarly, healthy attributions due to the maintenance of personal control in spite of beliefs in God were found in Jackson and Coursey's (1988) study of a sample of Black Baptists. In this study, high God control was correlated with high internal locus of control, and only internal locus of control predicted measures of coping skills and purpose in life. Because control is such an overriding concern in relation to coping, it is important to look at how religion and spirituality have been conceptualized as coping mechanisms in the literature.

\section{SPIRITUAL AND RELIGIOUS COPING}

In the religiosity and spirituality literature, perceived control has often been studied in terms of spiritual or religious coping. Pargament and his colleagues (1988) have conducted extensive work on religion as a coping resource, its relation to control, and its resulting positive or negative psychological effects. According to Pargament and Hahn (1986), events may tax an individual to the point that personal control is not likely, and thus, God represents a source of reassurance, support, and encouragement that people can use to cope with stress. However, giving a sense of control to God is not in itself strongly related to psychological well-being (Pargament \& Hahn). Instead, this God control must be integrated with a more personal sense of control. One common theme in the literature about control (but also a possible bias in Western thinking) is that internal, personal control tends to be healthy, whereas external control is maladaptive. Researchers often equate external control with dependence on fate or God. However, dependence on fate and dependence on God are not synonymous if the latter involves some degree of mutuality (e.g., Jackson \& Coursey, 1988). In fact, especially in the context of spiritual turning points, a dependence on God may improve one's personal sense of control and thereby improve psychological outcomes.

Berrenberg (1987) has examined the relationship between God and control. His Personal Control Scale (BPCS) includes a distinction between internal and external locus of control and proposes the existence of mediated control. Mediated control, according to Berrenberg, "reflects the belief that outcomes are indirectly 
produced by one's actions, abilities, and efforts. Here there is an external causal agent mediating between the self and the outcome" (p. 196). In other words, an individual may believe he or she has control over outcomes to the extent that he or she can obtain help in the fulfillment of those outcomes from an external agent, such as God. Thus, as mentioned above, this type of control may be more similar to internal control in its positive outcomes than to external control. A belief in mediated control does not appear to be related to maladjustment as is a belief in external control. Skinner (1996) has also noted that beliefs in powerful others have not been found to interfere with a sense of personal control. God can be seen as a benevolent source of control that magnifies the power of the self. This type of control has also been referred to as proxy control and participatory control.

Similarly, according to Pargament et al. (1988), there are four control-related coping styles based on beliefs about an individual's relationship with God. The self-directing approach is similar to internal control, in the sense that the individual perceives the self as being the center of control, while still believing in God. In the collaborative approach (clearly related to God-mediated control), the individual sees God as a partner in the coping process; thus, control is achieved through the relationship between the individual and God. In the deferring approach (related to external control), the individual relinquishes personal responsibility to God. Finally, in the pleading approach, the individual asks God to intervene for a positive outcome. The collaborative approach has been associated with better outcomes than the deferring, self-directing, and pleading approaches, especially in low-control situations (Cole \& Pargament, 1999). Pargament et al. (1988) also found that this collaborative coping style is correlated with intrinsic religious commitment, in which religion is the individuals' primary motive in life and is experienced as an end in itself. The benefit of this type of coping is also supported by the Jackson and Coursey (1988) study, in which effective coping in a sample of Black Baptists was achieved via personal control through God, as opposed to a belief in an externally-controlling God. Similarly, Ellison (1991) found that an intrinsic religious orientation can have more positive psychological outcomes than an extrinsic religious orientation, in which religion is often a means to an end (e.g., status, social interaction).

More recently, Cole and Pargament (1999) have developed the idea of spiritual surrender as a paradoxical pathway to control in the process of coping. According to these researchers, spiritual surrender is very different from the deferring style of religious coping; rather, surrender involves self-transcendence and is therefore characterized by "an enhanced state of being" (p. 185). Furthermore, "a greater sense of control may ensue from the act of surrender to the sacred" (p. 186). By surrendering to God in a situation in which personal control is not feasible, the individual may be better able to adapt to reality and may enhance the ability to take constructive action. Surrender may relate to collaborative coping because both the individual and God are active in solving the problem. Wong-McDonald and Gorsuch (2000) found that spiritual surrender was negatively related to 
self-directing coping and positively associated with the collaborative and deferring coping approaches and that surrender correlated positively with religious importance, intrinsic religiousness, spiritual well-being, and locus of control in God. Hypotheses based on a more specific attribution theory than the more general theory developed by Spilka et al. (1985) mentioned above, also seem to support the positive benefits of surrender (Proudfoot \& Shaver, 1976). Proudfoot and Shaver focused on individuals' interpretations of personal experiences and behavior. According to this theory, physiological arousal due to an external stressor can be reinterpreted in religious terms. This "changed cognitive set" (p. 327) then leads to a relaxed state, but this state is entirely dependent on trust in an external power. Paradoxically, many religious systems may enable an individual to reinterpret potentially discouraging events as further evidence for the truth of the system and for the efficacy of appropriate religious action, thereby possibly increasing personal sense of control.

Furthermore, Pargament and Hahn's (1986) concepts of collaborative problemsolving and surrender to God in the religious coping literature are clearly related to the concept of God-mediated control. In fact, the use of God-mediated control could be conceptualized as an umbrella term for these two concepts; God-mediated control is equivalent to a collaborative coping style until a stressor reaches a certain threshold, at which point an individual utilizing God-mediated control must surrender to God to (paradoxically) maintain a healthy sense of control. According to Cole and Pargament (1999), spiritual surrender is more likely to be used than a collaborative approach in more stressful situations, although both are associated with positive psychological outcomes. In a series of focus group discussions about the nature of prayer in late life, Krause, Chatters, Meltzer, and Morgan (2000) found that what appeared to be a rather passive approach to the use of prayer during difficult times among older adults was actually not passive at all. In fact, "the older adults let go of the worry associated with problems, but not the responsibility for remaining an active participant in working out the solution" (p. 207). This letting go of worry seems to exemplify Cole and Pargament's (1999) concept of spiritual surrender.

\section{TURNING POINTS}

Spiritual turning points were chosen as the context for this study because attention to religious exposures beyond "current religious practices" has been especially deficient in the literature. Turning points give shape to the trajectory of one's spiritual life. Thus, outcomes may be affected by the overall shape of the trajectory (Elder, 1995). Studying past turning points and their outcomes in the spiritual and psychological lives of the elderly can help researchers to better understand the impact of spirituality throughout the life course. Much of the conceptualization of spiritual turning points in this study comes from the more general concept of turning points found in the literature. 
The concept of turning points has been widely studied in both the sociological and psychological fields. The most prevalent and recent idea of turning points is based on the life course perspective (Elder, 1995). According to Elder, turning points are conceived as transitions or changes in state embedded in trajectories. The combination of trajectories and transitions define the social life course. According to the stress-crisis approach, turning points stem from life stressors that pose direct challenges to long-held plans and intentions and that cause severe psychological and physical distress. After experiencing such stressors, people report a loss of meaning in life, which when restored resolves the psychological dilemma. This resolution constitutes the turning point. Clausen (1995) used the life course paradigm to investigate turning points by emphasizing the narrative approach. Clausen classified turning points along two sets of categories: the major role affected or the kind of event that caused the turning point, and the nature and extent of change. Types of turning points include a change in a major life role, a change in perspective on life, a change in important life goals, and a change in the view of the self.

More recently, researchers have continued in the vein of the life course paradigm with an emphasis on the trajectory: its direction, its turning points, and its endpoints (Wheaton \& Gotlib, 1997). According to Wheaton and Gotlib, following Elder, a trajectory is a stable component of a direction toward a life destination, characterized by a given probability of occurrence. A turning point is a change in the direction in the life course that is nonnormative given an established baseline. A turning point may also be an intervention, or an attempt at changing the direction of the life course. This change in direction has the long-term impact of altering the probability of life destinations. Furthermore, the greater the extent to which the transition has some instrumental function (to alter identity, to resolve conflict, or to provide escape from prior stress), the more likely it is that it will be experienced as a turning point.

Wethington, Cooper, and Holmes (1997) looked at how individuals view and conceptualize the major turning points in their lives by developing a series of questions tapping experiences as potential turning points and based on a combination of the stress-crisis approach and the life-course perspective. These researchers discovered that it is the responses to past stressors, as much as the stressors themselves, which are seen as turning points. Types of turning points include self-insights, which involve a need to assert control over choices and the direction of life, and insights into situational factors.

Some researchers have examined sense of control and turning points. Thurnher (1983) combined subjective and objective approaches to studying turning points. Thurnher's study examined the effects of life events construed by respondents to represent major turning points in two ways: a subjective evaluation of their impact, and an analysis of the interrelationship between turning points and structured measures of self-concept and morale. Turning Point Impact Ratings were used, which involve the evaluation and summation of the described 
effects of separate turning points, categorized as positive, neutral, and negative. Thurnher found that high self-control was linked to positive impact of turning points. Thus, control is not only important in coping with stressful life events, but also appears to impact the shape of trajectories by affecting turning points and transitions.

\section{PERCEIVED CONTROL}

The stress-crisis approach and the life course approach, as well as research done in the tradition of these approaches, suggest that perceived control is a key ingredient to the outcomes of stressful life circumstances in terms of turning points and transitions. Perceived control is especially important to study in the context of turning points since triggers of turning points and the turning points themselves often involve changes in perceived or actual control. Perlmuter and Monty (1977) define control as the "continual attempt of the human or animal to deal effectively with and to manipulate his environment" (p. 759). They found a large body of data that indicates that the absence of control affects hidden psychological activity as much as it does overt behavior. For example, a lack of control can lead to feelings of helplessness. According to research done by Albert and Geller (1978), perceived lack of control, rather than the actual experience of uncontrollability, determined learned helplessness. Furthermore, people with an external locus of control are more susceptible to learned helplessness than are those with an internal locus of control. Whereas those with an external locus of control believe that rewards are largely determined by external forces such as fate, luck, chance, the government, or powerful others, those with an internal locus of control believe that their own responses largely determine the amount and nature of the rewards they receive. According to Craig, Hancock, Chang, and Dickson (1998), a person with less control over his or her immediate circumstances, such as someone suffering from a chronic illness, may be at risk for developing an external locus of control and a sense of helplessness. On the other hand, a sense of personal control is helpful in achieving a productive and meaningful life. Feeling in control of one's thoughts and feelings can act as an adaptive coping skill in the face of uncontrollable events.

Perceived control is an important construct in relation to turning points and transitions. When people perceive control as impossible, they may have a variety of negative responses: withdrawal, passivity, fear, depression, or distress (Skinner, 1996). On the other hand, when people feel that they have a high degree of control, they tend to exert effort and try hard. They show optimism in spite of failures and setbacks, and are initiated towards action. Triggers of turning points, such as traumatic life experiences, can undermine a sense of control. Adjustment to that lack of perceived control involves a search for meaning, reestablishment of perceived control or mastery, and the restoration of self-esteem. Thus, a sense of control changes the meaning associated with a traumatic life event. 


\section{SPIRITUAL TURNING POINTS VERSUS CONVERSIONS}

The literature on religious or spiritual turning points has been dominated by the concept of conversion. Rambo (1992) is one researcher who has focused on religious turning points in terms of conversion. According to Rambo, a religious trigger is the turning point when "the external religious story becomes relevant and compelling to the person and begins to be internalized" (p. 172). Furthermore, the feeling of new freedom when crossing the line into a new life, in the form of relief and joy, can be a powerful psychological experience. Rambo also explains that surrender to God and/or Jesus Christ is often a crucial turning point in the conversion process. He compares the process to overcoming alcoholism; an alcoholic is empowered to change at the point at which he or she acknowledges helplessness. Similarly, when a person "confronts his or her predicament as a lost sinner, the surrender to that knowledge and a surrender to Jesus Christ as a deliverer is the very point at which energy becomes available for a new life" (p. 175). With this surrender, the energy that was used to maintain the struggle is released to be used in other aspects of the person's life. This idea might relate to the idea of personal control and spiritual turning points. Perhaps this "energy" gives individuals a perceived sense of control to either change or reinterpret aspects of their lives.

Conversion seems to be a phenomenon most closely linked with adolescence and young adulthood, rather than middle and older adulthood (Ullman, 1989). However, the idea of a spiritual turning point must not always be synonymous with conversion. In fact, spiritual turning points represent a broader category than conversion. For instance, according to Rambo (1993), a conversion is a process in time, not a single event. A spiritual turning point, however, may be a single event. However, some of the spiritual turning points experienced by individuals in this study could certainly be classified as conversions according to Rambo's definition. Rambo defines several different types of conversion, one of which includes "intensification," or the "revitalized commitment to a faith with which the convert has had a previous affiliation, formal or informal" (p. 13). This is perhaps the most commonly experienced spiritual turning point in the present sample. Although Rambo's definition of conversion also allows for apostasy or defection, it does not allow for a decline or de-intensification. The broader concept of a spiritual turning point does include this possibility. Furthermore, whereas an encounter between an advocate and a convert, interaction with a new religious group, and commitment are integral stages to Rambo's model of conversion, none of these variables are necessary to achieve a spiritual turning point. The other stages of Rambos' model, however (i.e., context, crisis, quest, consequences), are often integral to spiritual turning points.

Importantly, the primary prerequisite of a spiritual turning point in this study is the subjective experience of such a turning point. In other words, if individuals believe that they had a spiritual turning point, then that belief is taken as evidence 
of such a turning point. Rambo (1993) similarly defined conversion as "what a group or person says it is" (p. 7). Many of the spiritual turning points as subjectively defined in the present study appear to be reactions to life stressors and the consequent coping involved. However, these life stressors can be considered "triggers" of turning points. Furthermore, according to Murrell, Meeks, and Walker (1991), personal resources are needed as coping devices in times of stress; this idea, closely related to the stress-crisis approach of turning points mentioned above, might be applicable to religious or spiritual resources as well and is important to understand in the context of spiritual turning points in this study. Because control becomes so salient in the context of a trigger such as chronic illness (because personal control is not feasible or likely to be effective), God is turned to especially in such situations (Pargament \& Hahn, 1986). Religion may provide meaning that aids in understanding illness and death (Ainlay, Singleton, $\&$ Swigert, 1992). Perhaps more importantly, religion can shape the appraisal of many types of stressful life events and the assessment of capacities to cope successfully (Ellison, 1991).

Finally, in line with Wheaton and Gotlib's (1997) definition of a turning point as including an attempt at changing the direction of the life course, and Wethington et al.'s (1997) emphasis on turning points as involving a need to assert control over choices and the direction of life, actions, decisions, and new interpretations are key to the concept of spiritual turning points as defined in this article. These actions, decisions, and new interpretations are closely linked with regained perceived control, exemplified below in the participants' narratives.

\section{THE PRESENT STUDY}

The current study involves an examination of control in the context of spiritual turning points as uncovered in the narrative histories of selected elderly participants. Elderly participants were chosen for several reasons. First, although formal religious participation seems to decline with age due to health problems, informal participation appears to increase slightly (Ainlay et al., 1992). Religion and spirituality are especially important as the elderly face their own mortality (McCue, 1995). Furthermore, health problems that are more common among the elderly, such as chronic illnesses, may be linked with religious commitments that may in turn affect subjective well-being, as well as physical health and social support (McFadden, 1995). In addition to their importance in providing information on individuals' spiritual histories, spiritual turning points were chosen as the context for the present study because of their implications for perceived control. As discussed above, perceived control is an important construct in relation to turning points and transitions. Triggers of turning points, such as traumatic life experiences, can undermine a sense of control. Adjustment to that lack of perceived control involves a search for meaning, reestablishment of perceived control or mastery, and restoration of self-esteem (as 
also predicted by attribution theory according to Spilka et al., 1985). Finally, previous research has shown that coping and perceptions of control in relation to spirituality arise as important themes within qualitative life story interviews (Wallace \& Bergeman, 2002).

The literature on religion and health, spiritual control and coping, and turning points and trajectories, all have applicability to the current question of spiritual turning points and perceived control. This article attempts to remedy a previous deficit in the literature; namely, a combining of theories from these various fields of research. Such a combination can be used to address important questions.

\section{RESEARCH QUESTIONS}

The present study examines spiritual turning points in terms of control and attempts to show that for the many people who derive benefits from religion and/or spirituality, God may act as a mediator. Using the narrative spiritual life histories of older persons, the following exploratory research questions are proposed:

1. How does the concept of perceived control relate to one's relationship with God and with psychological outcomes at the time of and years after spiritual turning points?

2. Furthermore, do some elderly who have experienced spiritual turning points and recall a sense of perceived control after the turning point interpret God as a mediator of that control?

3. How can God-mediated control be conceptualized within the context of spiritual turning points?

\section{METHODS}

\section{Design}

A sample of 30 participants was recruited from the Duke Aging Center Subject Registry, a listing of over 1,900 community-dwelling elders in the Durham/Chapel Hill/Raleigh area who expressed a willingness to participate in Duke Aging Center Research. Participants were invited to participate by telephone and were scheduled for an interview. Their informed consent was acquired. Interviews were approximately one to one-and-a-half hours in length. Interviews were recorded and transcribed for qualitative analysis.

\section{Sample}

Of the sainple, 12 were male, and 18 were female. Eleven of the participants were black and 19 were white. Ages ranged from 65 to 88, and the mean age was 75.5. Years of formal education completed ranged from 11 to 24 , with a mean number of years at 15 . Twelve participants were married at the time of the 
interview, 10 were widowed, one was single, one was widowed and divorced, and 6 were divorced. Please see Table 1 for further information regarding the participants. The participants were affiliated with 11 different denominations. Please see Table 2 for further information regarding the participants' denominations. Throughout the article, participants will be referred to using first name pseudonyms in order to protect anonymity.

\section{Measures}

The instrument was a semi-structured interview based on an extensive literature review (Hays, Meador, Branch, \& George, 2001). The closed-ended questionnaire items included demographic information and retrospective assessment of religious behaviors and beliefs in each decade of the lifespan. The open-ended questionnaire items invited the participants to discuss spiritual turnings, crises, and changes occurring over the lifespan, as shown in Table 3 .

\section{Analysis}

A generalized issue-focused analytic method was used (Weiss, 1994). Using NUD*IST qualitative analysis software, the data were analyzed and organized into themes. The answers to the questionnaire items concerning spiritual turning points were especially closely scrutinized. Thus, by focusing on the answers to these items and by using "turning point" as a search word in the NUD*IST program, only those experiences considered spiritual turning points by the participants were analyzed. The term "control" was not used as a prompt during the interview. Therefore, participants' feelings of control were inferred from participant-initiated terminology, again by entering in appropriate search words into NUD*IST. After the appropriate passages were located using the search function in NUD*IST, these passages were closely read (within the context of the entire interviews) and numerous themes were culled from these passages. These themes were then further reduced by combining similar ideas. Thus, the final set of themes was derived from this original set.

\section{RESULTS}

\section{Models}

A model of the preliminary framework for the current exploration of spiritual turning points and sense of control, as well as an elaboration of God-mediated control arising from the interviews, can be found in Figure 1. According to the top portion of this figure, those who turn to God regain a sense of control in their lives after a negative trigger, but those who interpret God as an all-powerful external agent still associate negative feelings with the turning point. Those who interpret God as a mediator of that control have positive feelings associated with the turning 
402 / FIORI, HAYS AND MEADOR

Table 1. Descriptive Statistics for Sample

\begin{tabular}{|c|c|c|c|c|}
\hline Participants & $N$ & $\%$ & $M$ & Range \\
\hline Age & 30 & & 75.5 & $65-88$ \\
\hline \multicolumn{5}{|l|}{ Age group } \\
\hline $65-69$ & 4 & 13.3 & & \\
\hline $70-74$ & 11 & 36.7 & & \\
\hline $75-79$ & 8 & 26.7 & & \\
\hline $80-84$ & 6 & 20.0 & & \\
\hline $85-89$ & 1 & 3.3 & & \\
\hline \multicolumn{5}{|l|}{ Gender } \\
\hline Male & 12 & 40.0 & & \\
\hline Female & 18 & 60.0 & & \\
\hline \multicolumn{5}{|l|}{ Race } \\
\hline Black & 11 & 36.7 & & \\
\hline White & 19 & 63.3 & & \\
\hline \multicolumn{5}{|l|}{ Birthplace } \\
\hline NC & 14 & 46.7 & & \\
\hline Adjacent SE states & 4 & 13.3 & & \\
\hline Florida & 2 & 6.7 & & \\
\hline Northeast & 4 & 13.3 & & \\
\hline Midwest & 3 & 10.0 & & \\
\hline Foreign & 3 & 10.0 & & \\
\hline Years of formal education & & & 15.0 & $11-24$ \\
\hline$<$ High school & 1 & 3.3 & & \\
\hline High school & 6 & 20.0 & & \\
\hline Some college & 10 & 33.3 & & \\
\hline College & 6 & 20.0 & & \\
\hline $1-3$ years postgrad & 4 & 13.3 & & \\
\hline $4+$ years postgrad & 3 & 10.0 & & \\
\hline \multicolumn{5}{|l|}{ Marital status } \\
\hline Single & 1 & 3.3 & & \\
\hline Married & 12 & 40.0 & & \\
\hline Widowed & 10 & 33.3 & & \\
\hline Widowed and divorced & 1 & 3.3 & & \\
\hline Divorced & 6 & 20.0 & & \\
\hline
\end{tabular}


SPIRITUAL TURNING POINTS AND PERCEIVED CONTROL ／ 403

Table 2. Denominations

\begin{tabular}{ll}
\hline Participants & \\
\hline Baptist & 8 \\
Christian Science and Baptist & 1 \\
Nondenominational Christian & 2 \\
Presbyterian & 1 \\
AME Zion & 1 \\
Methodist & 4 \\
Quaker & 1 \\
Unitarian & 1 \\
Episcopal & 1 \\
Roman Catholic & 1 \\
Jewish & 3 \\
Unaffiliated & 5 \\
Agnostic & 1 \\
\hline
\end{tabular}

point. The bottom portion of the figure is further explained below. It is important to note that whereas the top portion of the figure was created from a priori research questions (see Research Questions 1 and 2), the bottom portion of this figure was developed post-hoc, from the analysis of the data (see Research Question 3).

\section{Initial Sense of Perceived Control}

The model begins with an initial sense of perceived control. Among the participants of this study, this initial sense of perceived control was implied by the loss of such control at the time of triggers of spiritual turning points. This loss of perceived control is discussed below.

\section{Patterns and Triggers of Spiritual Turning Points}

In response to the probe regarding "points of special religious or spiritual significance," participants reported 0 to 8 spiritually significant turning points per participant. Only three participants did not report any spiritually significant turning points. Out of 109 total turning points, almost half (47) occurred in mid-life (defined as ranging from ages 35 to 69). Of the rest, most occurred during young adulthood, with very few occurring during childhood or late adulthood. No significant differences in frequency or type of turning point emerged based on race or years of education. Females had more spiritual turning points triggered by 
Table 3. Spiritual History Interview Probes (Excerpt)

In thinking back over your life up to now, have there been points in your life that have had special religious or spiritual significance to you?

- If so, tell me about the first one.

- What happened?

- When did it happen?

- How old were you?

- Did the experience change your life in any significant way?

- Did that event cause you to do anything different in your life?

- What feeling or feelings do you associate with that point in your life?

-Would you say that the experience caused a turning point in your life?

Repeat above sequence as needed.

What would you rank as the three most important events of any kind in your life?

- Did any of these events change your life?

- In what way?

- Did it cause you to do anything in a new or different way?

- Did it cause you to think about your life in a new way?

- Would you call any of these events a turning point in your life?

Do you believe that God is active and involved in your day-to-day life?

- If yes, in what ways?

- Have you always believed this to be so?

From your experience, what have you come to believe is the best answer to each of the following questions:

What religious, spiritual, or ethical principles do you use to determine how you live your life?

- From whom did you learn them?

Do you think that your early spiritual history has had any effect on your late life health?

- In what ways? 
SPIRITUAL TURNING POINTS AND PERCEIVED CONTROL ／ 405

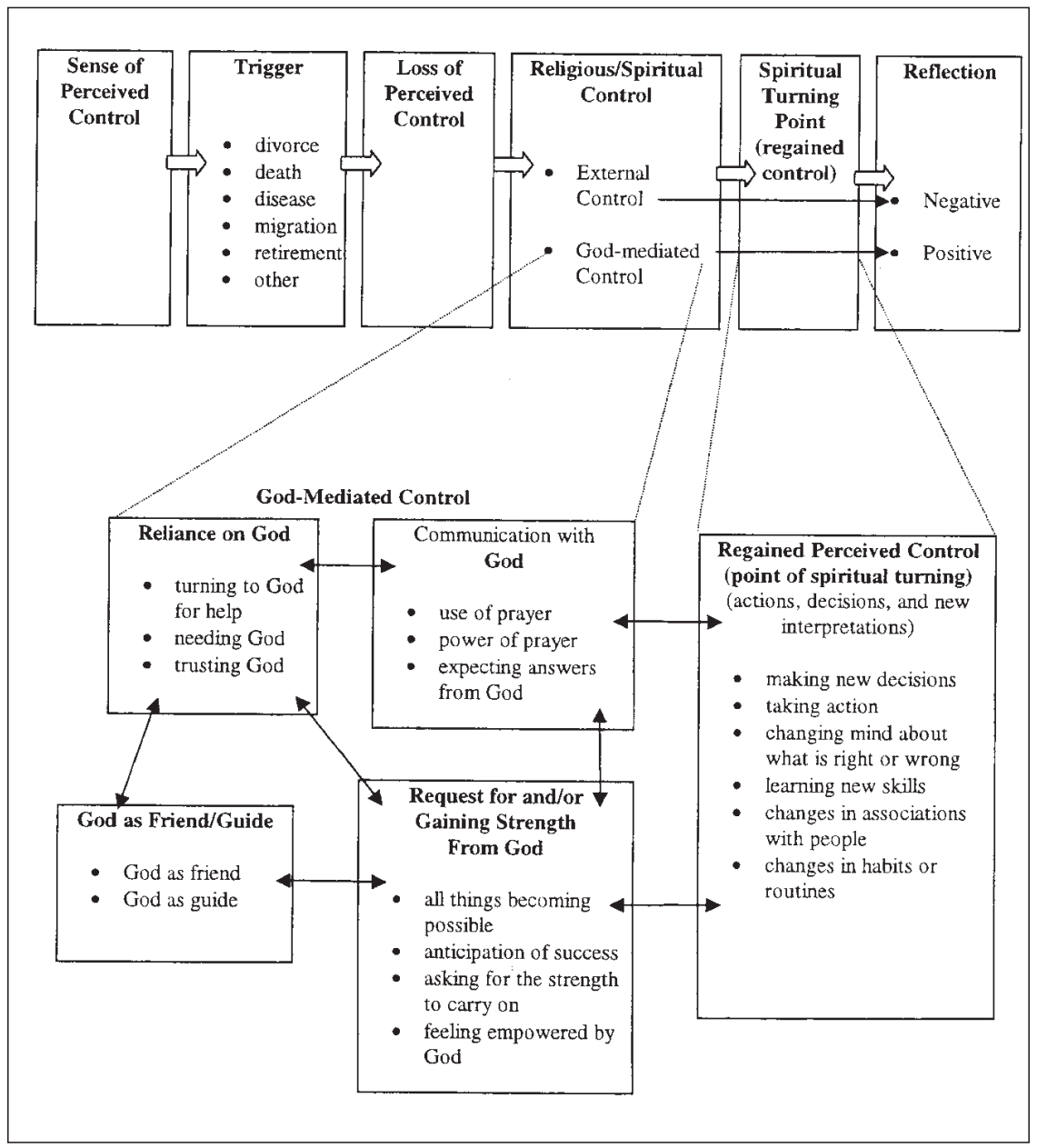

Figure 1. A conceptual model of spiritual turning points and control and an elaboration of God-mediated control.

losses $(70 \%)$ than did males $(43 \%)$. Most of the spiritual turning points were triggered by a loss (i.e., death, divorce), and most were permanent (i.e., lasting) as opposed to episodic (e.g., a change lasting only a year or so). Betty, for example, had a permanent turning point upon joining the Quaker Friends while battling through a divorce; she started going to the Friends' Meetings and "kept going there" for the spirit, peace, and understanding that she enjoyed while there. Rachel, on the other hand, had an episodic turning point. She stopped going to church for a year after the death of her sister: "It took me about a year or so to get over that, and went on back to the church. But I was angry for a while there." 
Loss triggers included deaths of a mother, father, husband, sister, aunt, or uncle. Susan, for instance, turned to religion upon the death of her mother: "I never went for spiritual guidance except one time when my mother died. That was the first time that I felt that I had a real need to speak to a rabbi." Other loss triggers included divorce, injury, surgery, birth of a handicapped child, and diagnosis of illness. Gain triggers included the birth of a child and attendance at a new church. For instance, Diane, commenting on the birth of her child, recalled that she and her husband "became increasingly closer (we hoped) to God. Because we knew that we were bringing a child into the world."

\section{Loss of Perceived Control}

Many of the participants reported a loss of perceived control at the time of triggers of turning points. These triggers were often negative events that resulted in a loss of feeling connected to or in control of one's life. Some of these people ended up turning to God. For instance, Ellen reported: "Right after that, going through the trauma of not really having parents, not really having a home, not really feeling that I was really wanted - ah-is when I turned to God . . that was the great turning point in my life." Sara relied on God to help her through a recovery from an accident: "I couldn't walk, and ... I was very depressed at that time, because I wasn't sure that I would walk again."

A lack of control can also lead to a turn away from God. Roger experienced a turning point away from the church when he was thrown off the Deacon Board as a result of a conflict. When asked about his feelings during that period, he said (in relation to the man with whom he had had a conflict), "It's just conflict between the two of us - he had the power and I didn't. That was the way it was." Thus, Roger felt that he did not have control over the situation. Rachel became very angry with God when she was not able to get to her sister before she died: "I didn't get there before she died. And I was very angry about that. I-I didn't see why I didn't get there. . . . I stopped going to church because I was-I was really angry."

\section{External Control}

Two types of religious or spiritual control are considered in the model: external and God-mediated. A few of the participants seemed to have a greater sense of external control after their transition. After her son was murdered, Nicole felt very numb and seemed to lose a sense of perceived control. But then she turned to God: "Yeah, it's been hard. But I've been able to just turn it over to the Lord ... the Bible says it's a sin to worry, and I believe it. ... God got the power." Rather than form a working relationship with God, her words seem to imply that she gave all control to God, thereby developing a sense of external control. 


\section{God-Mediated Control: Themes and Relationships}

Several themes emerged from the interviews that indicated how God-mediated control was associated with the process of coping and how such a process might help a person to regain perceived control and reflect on their turning point positively. These themes included God as friend and/or guide, reliance on God, request for and/or gaining strength from God, communication with God, and regained control. These five themes and their relationship to each other are modeled in the bottom portion of Figure 1. While reading the following sections, it is important to consider the possibility that some of the denominations represented in this sample are more likely than others to reinforce some of these concepts (e.g., God as a friend or a guide). Furthermore, persons associated with Christian denominations, which stress Trinitarian theology, may also emphasize "Jesus Christ" or even the "Holy Spirit" in their descriptions of spiritual turning points. Such statements are included in the following sections.

\section{God as Friend and/or Guide}

Participants' relationships with God were a frequent starting point for the way in which they dealt with a stressful event from a religious or spiritual perspective. Several types of relationships with God were important as mediators of control. The most prominent of these was God as a guide and God as a friend, or a combination of the two. Many participants interpreted God as a guide, i.e., one who directs a person in his conduct or course of life. Peter was trying to decide whether or not to go through with surgery for his prostate cancer. His doctor recommended the surgery, and Peter responded, "Well, my body is in God's hands, but also in your hands. I know God is going to guide you." Peter obviously believed that the doctor had some control over the situation and that the surgical outcome was not predetermined or completely out of earthly control. Although Peter did not have personal control, he relied on God to be a guide for the surgeon. Dan responded that God "guides me, and He watches over me ... in the morning, I ask him to guide and direct me through the day, and keep His strongest armor of protection around me and those I'm entrusted with." Michelle explained that in order to get through difficult times, she depended on God "as my guide, to bring me through whatever... God is there for me, and that He will be everything that I'll let Him be, to me. And, uh-when I step out of line, that's me, and I've got to step back.... I'd always ask God to lead me and guide me as to what I should do, about anything. . . . He's my source." In such relationships between God and the individual, God acted as a source of information and support, but ultimately it was up to the individual to make a decision or take an action.

Many participants in this study also understood God (or Christ) as a friend. After he and his wife joined a group at a church in Washington, D.C., Christopher 
explained that "to them, Christ was different-instead of being somebody you studied about and heard about in Sunday school, it was someone they knew, like someone they depended on, and a friend. And this was different and very attractive." After this spiritual turning point, he said, "Instead of saying prayers nominally because that was what you were supposed to do, you had conversations with Christ, because He was more important- He was my friend. And we had a closer relationship." Peter considered that event "life-changing, and now very positive." After her husband died, Amy was able to cope because she "felt that God and my husband were looking out for me. And, um, and I still feel like he watches over me. And God, um-I always felt like I had a personal relationship with God. I could talk to Him, you know." A friendship implies a reciprocal, dyadic relationship. Thus, God did not simply act upon the lives of these individuals; rather, they participated in a relationship of mutuality. The participants' relationships to God indicated the role that God played in their lives. These roles included that of a guide and that of a friend.

\section{Reliance on God}

Reliance on God was a frequently cited mechanism of God-mediated control in stressful circumstances. Some participants relied directly on God in the form of asking for help. Frank prepared to tell his mother about his father's death: "I just asked the Lord to give me some help." After his mother accepted her husband's death he considered it "a miracle." When Justin realized he had a "false impression of life," he began reading the Bible more and "felt a need, for that I didn't have." So he joined the church. Thus, his change in perspective on life was instigated by a need, which he interpreted as a need for God: "I saw a need to come to God, that was a turning point, and I turned."

Other participants described their reliance on God more generically. For instance, Rachel, in order to explain how she got through stressful times, said, "You rely on your Christian faith to help you through difficult times. And, that is just the way of life, really." As she was recovering from depression Sara said, "Just believing in God helped me, and took me through it." Thinking back to a stay in the hospital after a car accident, Sara answered the question "How do you think believing in God helped you through?" by saying, "He had helped me this far through life, and-I can't explain; I guess it's just believing that He would be there for me." Michelle explained that "God could do it all-everything. We only had to trust in Him." A need to turn to God and trusting in one's faith were important components of God-mediated control for these participants. This reliance involved a confidence between the person and God, which also indicates trust. Thus, reliance on God, which implies a certain power distribution, was an important step for many of the participants in reaching a spiritual turning point. 


\section{Request for and/or Gaining Strength from God}

Several participants for whom a negative trigger preceded a positive spiritual turning point discussed "strength" or a related concept, such as feeling empowered by God, as a component of their relationship with God. A request for strength implies that some control resides in the requester's hand. After receiving strength from God, individuals could then produce their own outcomes. As Brenda noted, "I think I can ask for the strength to meet it. . . . I can ask for the strength to do the right thing. But I don't think The Man's memory bank is big enough to take care of millions of people asking for special favors." Stephanie described the time of her husband's deterioration from Alzheimer's disease as spiritually significant: "I had to call on that strength, you know, that there's something beyond me." Peter, upon the burial of his father, recalled having to ask the Lord, "Give us strength and courage to do things that will be pleasing, and acceptable unto You, and that Daddy would want to have done at his burial." Nicole recalled the trauma of her separation with her husband and how she told the Lord, "It's just going to take everything I can get from You, to do it."

Feelings of empowerment also characterized many participants' relationships to God. Maya remembered the trauma of her divorce and how she coped: "When you got God, you don't need it! You've got it all! You can do it, you know!" One interesting twist on this concept of empowerment is embodied in a comment made by Peter, recalling his fight with prostate cancer: "I asked the good Lord to give me strength to accept my fate." Thus, Peter interpreted his cancer as caused by fate, and the "good Lord," his means of strength to accept it and cope with the disease. God-mediated control is also implicit in this instance since God acted as a mediator between the individual and the outcome (the acceptance of the disease). Thus, in all of these requests for strength, the substance or nature of God's assistance to individuals utilizing God-mediated control becomes clear. Although God was giving the means through which these individuals felt that they could succeed (e.g., strength and courage), the individuals themselves were actually performing the actions to produce the outcomes. The sense that God was empowering the individual was also key in these participants' relationships to God and in the mediation of control among these participants.

\section{Communication with God}

Many of the participants used prayer to God as a means to control themselves and others. Although the use of prayer was implied in the discussion of the participants' relationship to God, reliance on God, and requests for strength from God, these components can be simply precursors to the use of prayer, whereas the participants often more explicitly indicated prayer as a form of communication with God. For instance, Laura commented, "Sometimes I pray the most before I get in my car and take a trip by myself. I have great respect for the automobile because I do think it's a dangerous weapon. And I do feel that God has been 
good to me in driving my cars because I have not had any serious accidents." Laura felt that by praying, she protected herself from possible injury and maintained some personal control over the outcomes in her life. Dan, a school bus driver, also said that praying protected him from potential car accidents:

I've had so many narrow escapes on these highways and byways on that bus. . . . Now, I know if it weren't for Him . . . I think I'd have been-may have had a collision. I'd either have had some wreck-some wrecks some of these other buses had, have hurt up a lot of children or something. . . . Because that's one of the things I-I make mention in my prayer every morning and at night.

Christine said, "I have never prayed for anything that I wanted, and I didn't get." Rick went through a spiritually significant time when the woman he loved married someone else; he prayed to the Lord to stop him from loving her: "I prayed to the Lord. ... I would ask the Lord to stop me from loving this woman. ... A And I prayed like that . . . every night, for about six months. . . . And finally, it was gone." Again, Rick felt that through his prayer, God helped him to stop loving this particular woman. For Rick, a reliance on God and communication with God were both important components in the mediation of control.

Peter, in response to the spiritual turning point of his son, said that he helped his son turn around by telling him, "What you need to do is pray. Just go somewhere in your quietness, and just pray and pray and pray. And God will give you an answer. It may not be the answer you want." In response to how she dealt with hard times, Laura said, "I pray. And I believe that God hears me, and He doesn't always answer me the way I want to be answered, but I do pray." These participants expected an answer, even if they didn't get the answers that they wanted. Others didn't even expect an answer, per se. Rachel, to explain how she got through stressful times, said that "you have problems, you pray about it. And then, you make a decision that from now on, whatever... Y You pray about it, and let it - and then let it alone." She trusted God to help her make the right decision and left the rest up to God. Rachel's relationship with God (which involved trust) preceded her use of prayer as a means of communication with God. Thus, the mechanism of interaction with God for many of these participants was prayer. Through prayer, which involves effort, these participants obviously felt that they could obtain "good outcomes" (such as successful funeral arrangements) and avoid undesirable situations (such as car accidents). This idea of some level of personal control in relationship to God is key to the concept of God-mediated control.

\section{Regained Perceived Control}

Regained perceived control often followed spiritual turning points. Actions and decisions are key issues involved with turning points. Thus, the actions, decisions, and new interpretations that the participants in this study made due to a spiritual 
turning point should be closely linked with God-mediated control. We found that they often were. Amy, upon the death of her husband, recalled thinking, "God is watching me. And I just can't sit back and become an invalid, or let life pass me by. I have to do what I can do." Amy was impelled into action (i.e., she sold her house and her RV) by the very belief that God was "watching" her. She remembered this time as a turning point. Thus, following a major loss, she was able to realize and accept change in herself. Ellen commented that during hard times, "God is there for me, and ... He will be everything that I'll let Him be, to me. And, uh-when I step out of line, that's me, and I've got to step back." According to Ellen, therefore, God was there but would only help her as much as she was willing to be helped. In the end, she believed that individuals must determine their own outcomes. When asked, "Did the experience change your life in any significant way-the experience of getting closer to the Lord?," Nicole responded, "Yes. . . It's when I made a change because I worked real hard and I had to go to work early in the morning at the hospital." Thus, the spiritual turning point resulted in a decision to work harder and the initiative to take action. Nicole took control of her life, with God's help. Deirdre “didn't look to God as somebody that was going to hand me out anything. You had to scrap for what you were gonna get." Susan said, "Certain things ... a are decided by God. They are going to happen. Not that $\mathrm{He}$ has decided, but you have to do your share, help yourself, and God will help you." All of these statements indicate a sense of God-mediated control, since with this type of control the individual (who is empowered by God) determines outcomes.

The relationship between perceived control and action can be clearly seen in a few of the comments made by participants. For instance, Roger recalled a time in which his life was out of control, until he joined the church:

I was about 30 years old, and by that time I had done drunk enough liquor and beer to explode a battleship and I was getting sick of it, tired of it. And I reckon to call it a spiritual experience, I reckon. I joined the church and I was - what do you call it? Gung-ho? ... And I was Sunday school teacher, and I was Communion Director. When the teacher was sick, I preached. And for about five, six, or seven years, I reckon, I was Deacon of the church, after a while.

Thus, Roger was able to regain control of his life through the actions he took involving the Church. His turning point involved not only a change in a major life role, but also a change in perspective on life and a change in important life goals. Several participants maintained that due to a spiritual turning point, they felt more in control of their lives than others did or felt more capable of producing their own outcomes. For example, Justin commented that if he had not turned to God, he doubts that he "would be alive today." He not only felt that he was "capable of maintaining [his] own well-being" in spite of serious health setbacks, but that his 
seemingly healthy brother "would not have died (had he) been able to find that which is good for him." Justin attributed his sense of personal control to God.

Another aspect of regained perceived control at the time of a spiritual turning point is closely related to the concept of interpretive control. Interpretive control, according to Thompson and Collins (1995), is a form of secondary control that refers to reinterpreting an event to make it more acceptable. This is also related to the importance of attributions and meaning-making as stressed by some psychologists of religion (e.g., Proudfoot \& Shaver, 1975; Spilka et al., 1985). For instance, John, upon the loss of his sister in a school bus accident, said:

And sometimes you know when a thing like that happens you ask yourself, "Wow, ... . why this one?" Because I know that she had been trained to be a believer, hadn't done bad things. But you don't know why these thingsometimes God takes the jewels. In other words he takes the pearls, to let you know what the rocks, whatever, they are of value, you know.

Thus, John reinterpreted the event to make it more acceptable. The loss was not meaningless; rather, God took his sister for a reason-in order to make him and others more aware of the value of hidden "jewels." Laura recalled a traumatic event of her childhood: "God was the most important thing that we should think of . . the death of the uncle and aunt probably hurt me as much as anything." However, she went on to say, "It made me think about life and the positiveness of it." In this way, she took a negative event and interpreted it in such a way that she was able to see the positive. These reinterpretations could have implications for control. If events are occurring haphazardly, for no reason at all, then a sense of control is obviously not feasible. However, if events are reinterpreted to occur for certain reasons, then perceived control is much more likely. Thus, regained perceived control among these participants involved both actions and decisions as well as new interpretations.

Relationships among God-Mediated Control Domains and Regained Perceived Control

The implied interplay of several of the components of God-mediated control in relation to a specific component, communication with God, has already been briefly mentioned above. In addition, several participants described a chronology of steps in God-mediated control. These descriptions further suggest how the several domains may relate to each other. For instance, as quoted above, Rachel said of stressful times, "You rely on your Christian faith to help you through difficult times. ... You have problems, you pray about it. And then, you make a decision that from now on, whatever. ... I accept." Thus, reliance is a first step, prayer is a second, and personal decision is a third. Ellen said, "I'd always ask God to lead me and guide me as to what I should do, about anything. ... He's my source. And I would always want to feel comfortable, uh, after talking with Him about what I was going to do.” Again, this reliance on God as a source leads 
to a feeling of comfort in communicating with God about possible decisions or actions. Diane explained why the birth of her son was a religiously significant event: "You become responsible for not only your own actions, but the course that you set for somebody else to follow." She handled the implications of this responsibility "just through prayer." She and her husband "became increasingly closer (we hoped) to God. Because we knew that we were bringing a child into the world." Thus, Diane realized that she was not only in control of her own life, but the life of another, as well. Thus, she looked to God (mainly through prayer) as a means of being able to handle this responsibility. The arrows in Figure 1 indicate possible pathways.

\section{Reflection}

Looking back on spiritual turning points, participants described both positive and negative reflections. There was some preliminary evidence for a connection between the use of God-mediated control and positive reflection on spiritual turning points (as visualized in the top portion of Figure 1). For example, Peter asked the Lord for strength and courage and trusted in God to guide him through two difficult times: the death of his father, and surgery for his prostate cancer. In reflecting back on these seemingly negative events with which he coped using features of God-mediated control, Peter said, "I don't think God provides anything that's negative to anybody. I think He prepares you if you ask Him to cope with any problem." This statement was extremely optimistic. Rick used God-mediated control by praying to God to stop loving a particular woman. However, he explained that he and the woman are "still friends today, best of friends." Christopher, who went through a spiritual turning point when he joined a group of people that viewed God as a friend, recalled that turning point as "life-changing, and now very positive. A happy experience." Thus, the use of God-mediated control may be linked with positive reflection on spiritual turning points.

The use of external control, on the other hand, sometimes appeared to be linked with negative reflection on spiritual turning points. Such negative reflection could be one way in which external control may exert a negative influence on well-being more generally across the lifespan. For example, Rachel went through a time that she did not go to church due to anger stemming from the death of her sister and the fact that she did not get to see her sister before she died. Rachel remembered her father telling her that it was not hers "to question the ways of God." She eventually got over the anger and returned to church, but she did not recall this occurrence positively. In fact, when asked how she resolved it in her mind, Rachel responded, "Well, I couldn't - the Bible is a very strange book, and you have to just accept some things. I never resolved it. I never-I never did understand why I didn't get there." The advice from her father, to not "question the ways of God," may be deemed closely related to the idea of external control. Her father seemed to suggest that God had all the power and the individual should not 
question God's ways (as one might question a friend or a guide). Perhaps as a result, Rachel recalled her feelings upon returning to church as not entirely positive. Allison spoke of her turning away from the church upon the birth of her retarded daughter and explained:

And I felt, again, this is one of the myths of religion: to teach you that God is going to cure everything, and to believe that there is some higher power that's going to solve all your problems, instead of you doing something yourself. And that was after my period of denial. . . . I didn't see religion as offering any answers. Now again, if I had been going to church, maybe I would have found some comfort in that, but at that point I was stopping.

Allison appeared to have believed that, whereas religion advocated external control in relationship to God, some degree of personal agency was important in coping with problems.

\section{DISCUSSION}

Based on several a priori research questions and the discussion of spiritual turning points and control that was culled from the transcripts used in the present study, two models were developed. One, found in the bottom portion of Figure 1, encapsulates the relationships among the various themes of God-mediated control. The second model, found in the top portion of Figure 1, proposes a hypothesized pathway among the relevant constructs. However, future studies will have to examine the validity of these models. Although the top portion of the model is especially difficult to substantiate given the present data, there is some evidence within the interviews to indicate a relationship between recall of the type of control during a spiritual turning point and the interpretation of the outcomes of that turning point in late life (as discussed in the section titled "Reflection"). Based on the psychological literature concerning control, an external locus of control appears to have detrimental outcomes, whereas an internal locus of control has more positive outcomes. Despite the proven benefits of religion and spirituality, negative effects have also been found and are often linked to the ways in which people view their relationship to God. Different religious interpretations have different outcomes for psychological health (Pargament \& Hahn, 1986).

One way in which people's interpretations vary may stem from differing loci of control. An assumption of this project was that an external locus of control has more negative psychological outcomes than does a sense of mediated control in the context of spiritual turning points. An external locus of control is the belief that rewards are largely determined by external forces. Mediated control reflects the belief that one has control over outcomes to the extent that he or she can obtain help in the fulfillment of those outcomes from an external agent, such as God (Berrenberg, 1987). In past research, this belief may have been misclassified as externality. However, whereas a belief in direct external control is related to 
maladjustment, it can be argued that a belief in mediated control is not. Rather, mediated control may have the same benefits derived from a belief in direct internal control. Future research is needed to more formally test this possibility.

Because religion appears to become more important to people as they age, studying past religious practices or spiritual experiences can be particularly important in understanding the current physical and psychological health of the elderly. Aging and quality of life among the elderly cannot be understood fully without knowledge of the prior life course. Furthermore, according to Eizenman, Nesselroade, Featherman, and Rowe (1997), a high sense of perceived control is a hallmark of successful aging. Thus, the question arises as to how past feelings of perceived control can affect present psychological and physical health of the elderly. Perhaps perceived control at different times throughout the lifespan gives a sense of an ability to determine the shape of one's life (Weisz \& Stipek, 1982). Or perhaps simply reviewing one's life and looking back positively on undesirable events as a result of perceived control at that time can have beneficial effects on one's psychological health in old age. Again, this possibility needs to be examined in future research, as the present study was only exploratory in nature.

This study examined this important factor (perceived control) and its relationship to a past spiritual experience (a turning point). Many of the participants in this study experienced triggers that resulted in feelings of helplessness. According to the research done by Albert and Geller (1978), these feelings of helplessness likely stem from a perceived lack of control. These losses in perceived control allowed for an examination of the transition to a regained sense of control, God-mediated or otherwise. Turning points are one component of an individual's narrative history that helps to give shape to that individual's life trajectory. As characterized by Wheaton and Gotlib (1997), turning points can be an intervention or an attempt at changing the direction of the life course. Turning points can also be self-insights that involve a need to assert control over choices and the direction of life (Wethington et al., 1997). According to Thompson and Collins (1995), "An important part of human experience is the extent to which people feel able to obtain good outcomes and avoid undesirable situations as a result of their own efforts" (p. 12). According to Skinner (1996), people who feel that they have a high degree of control tend to exert effort and try hard. They show optimism in spite of failures and setbacks, and are initiated toward action. Thus, perceived control is very important for positive psychological health and may promote the initiation of action. In relation to spirituality, control of this type can be Godmediated, as evidenced by the participants in this study. Because both religion and sense of control can shape the appraisal of many types of stressful life events and the assessment of capacities to cope successfully (Spilka et al., 1985), an analysis of the association between perceived control and an individual's relationship with God can be extremely important in understanding outcomes for psychological health. 


\section{Limitations and Future Research}

There are several limitations to the present study. First, the study is exploratory, and thus, no hypotheses were tested. Rather, the research questions were addressed in terms of the data stemming from the narratives. Future research needs to address these questions more systematically, using both quantitative and qualitative data. Second, the participants in this study are all of a Judeo-Christian background. Clearly, control and well-being may have quite different implications for individuals of other religions, such as Eastern religions. The emphasis on the importance of personal control in this article may be biased by Western and/or Protestant thinking. Future research needs to examine the concepts of spiritual turning points and control in the context of other religions and must also more closely examine differences by denomination.

Third, the small sample and qualitative nature of the data did not allow for a more detailed examination of differences that may have arisen based on race and gender. Although no main effect turning point differences were found for race and only one was found for gender, it is clear that interactions among turning points, control, and well-being may differ depending on these sociodemographic variables. For instance, not only do African Americans generally report higher levels of religiosity than do Whites (Levin, Taylor, \& Chatters, 1994; Taylor, Mattis, \& Chatters, 1999), but evidence also exists that externality may in fact be healthier for African Americans than for Whites because of what has been termed "system blame" (Neighbors, Jackson, Broman, \& Thompson, 1996). This concept refers to a process whereby African Americans blame the system, rather than themselves, for discrimination. Interestingly, in a study by Neff and Hope (1993), fatalism combined with religiosity actually decreased depressive symptoms in a study of African Americans in Texas. However, it is important to note Jackson and Coursey's (1988) finding that for Blacks, a strong belief in God control did not preclude a belief in personal (internal) control. Furthermore, religiosity and control also seem to differ by gender. Females report higher levels of religiosity than do men and locus of control appears to be different for men and women (Levin et al., 1994). Future research needs to examine race and gender more closely to determine whether similar relationships among control, spiritual turning points, and well-being can be found among these different sociodemographic groups.

In spite of these limitations, this study has important implications for the way in which a healthy sense of control should be promoted among religious individuals. In such a population, a fine psychological balance exists between a protective relinquishing of control and a possibly problematic passivity. Teachers, practitioners, caseworkers, therapists, and clergy must consider individuals' relationships to a higher power when providing counseling, especially during times of stress and possible turning points. Such sensitive counseling may be particularly important among older adults as religion becomes more important and personal control begins to decline. The idea of God-mediated control may be one concept 
that could be brought to religious therapy groups to encourage a healthy balance between personal control and surrender to God. If God-mediated control is in fact healthier than external control, then people experiencing trauma may find that a spiritual or religious intervention or support group advocating this type of control is quite beneficial. Furthermore, a model of God-mediated control and late life well-being could prove to be very useful in the field of gerontology. Knowing an elderly person's spiritual history is crucial in understanding his or her physical and mental health situation. Because turning points are such life-altering experiences, they are particularly important phenomena to understand. Finally, by further developing the little researched phenomenon of the spiritual turning point, this study can act as a foundation for future studies.

\section{REFERENCES}

Ainlay, S., Singleton, R., \& Swigert, V. (1992). Aging and religious participation: Reconsidering the effects of health. Journal for the Scientific Study of Religion, 31, 175-188.

Albert, M., \& Geller, E. S. (1978). Perceived control as a mediator of learned helplessness. American Journal of Psychology, 91, 389-400.

Barlow, S. H., \& Bergin, A. E. (1998). Religion and mental health from the Mormon perspective. In H. G. Koenig (Ed.), Handbook of religion and mental health (pp. 225-243). San Diego: Academic Press.

Berrenberg, J. L. (1987). The belief in personal control scale: A measure of Godmediated and exaggerated control. Journal of Personality Assessment, 51, 194-206.

Bulman, R. J., \& Wortman, C. B. (1977). Attributions of blame and coping in the "real world": Severe accident victims react to their lot. Journal of Personality \& Social Psychology, 35, 351-363.

Clausen, J. A. (1995). Gender, context, and turning points in adults' lives. In P. Moen, G. H. Elder, Jr., \& K. Luscher (Eds.), Examining lives in context: Perspectives on the ecology of human development (pp. 365-389). Washington, DC: American Psychological Association.

Cole, B. S., \& Pargament, K. I. (1999). Spiritual surrender: A paradoxical path to control. In W. R. Miller (Ed.), Integrating spirituality into treatment: Resources for practitioners (pp. 179-198). Washington, DC: American Psychological Association.

Craig, A., Hancock, K., Chang, E., \& Dickson, H. (1998). The effectiveness of group psychological intervention in enhancing perceptions of control following spinal cord injury. Australian and New Zealand Journal of Psychiatry, 32, 112-118.

Dein, S., \& Stygal, J. (1997). Does being religious help or hinder coping with chronic illness? A critical literature review. Palliative Medicine, 11, 291-298.

Eizenman, D. R., Nesselroade, J. R., Featherman, D. L., \& Rowe, J. W. (1997). Intraindividual variability in perceived control in an older sample: The MacArthur successful aging studies. Psychology and Aging, 12, 489-502.

Elder, G. H., Jr. (1995). The life course paradigm: Social change and individual development. In P. Moen, G. H. Elder, Jr., \& K. Luscher (Eds.), Examining lives in context: Perspectives on the ecology of human development (pp. 101-133). Washington, DC: American Psychological Association. 
Ellison, C. (1991). Religious involvement and subjective well-being. Journal of Health and Social Behavior, 32, 80-99.

Hays, J. C., Meador, K. G., Branch, P. S., \& George, L. K. (2001). The spiritual history scale in four dimensions (SHS-4): Validity and reliability. The Gerontologist: Special Issue, 41, 239-249.

Idler, E. I., \& George, L. K. (1998). What sociology can help us understand about religion and mental health. In H. G. Koenig (Ed.), Handbook of religion and mental health (pp. 51-62). San Diego: Academic Press.

Idler, E., \& Kasl, S. (1992). Religion, disability, depression, and the timing of death. American Journal of Sociology, 97, 1052-1079.

Idler, E., \& Kasl, S. (1997). Religion among disables and nondisabled persons II: Attendance at religious services as a predictor of the course of disability. The Journals of Gerontology, 52B, S306-S316.

Jackson, L. E., \& Coursey, R. D. (1988). The relationship of God control and internal locus of control to intrinsic religious motivation, coping and purpose in life. Journal for the Scientific Study of Religion, 27, 399-410.

Koenig, H. G., Hays, J. C., Larson, D. B., George, L. K., Cohen, H. J., McCullough, M. E., et al. (1999). Does religious attendance prolong survival? A six-year follow-up study of 3,968 older adults. Journal of Gerontology, 54A, M370-M376.

Krause, N., Chatters, L. M., Meltzer, T., \& Morgan, D. L. (2000). Using focus groups to explore the nature of prayer in late life. Journal of Aging Studies, 14, 191-212.

Levin, J. S., Taylor, J. R., \& Chatters, L. M. (1994). Race and gender differences in religiosity among older adults: Findings from four national surveys. Journal of Gerontology, 149, S137-S145.

Levin, J., \& Vanderpool, H. (1989). Is religion therapeutically significant for hypertension? Social Science and Medicine, 29, 69-78.

McCue, J. (1995). The naturalness of dying. Journal of the American Medical Association, 273, 1039-1042.

McFadden, S. (1995). Religion and well-being in aging persons in an aging society. Journal of Social Issues, 51, 161-175.

McIntosh, D. N., Silver, R. C., \& Wortman, C. B. (1993). Religion's role in aqjustment to a negative life event: Coping with the loss of a child. Journal of Personality \& Social Psychology, 65, 812-821.

Miner, M. H., \& McKinght, J. (1999). Religious attributions: Situational factors and effects on coping. Journal for the Scientific Study of Religion, 38, 274-286.

Murrell, S. A., Meels, S., \& Walker, J. (1991). Protective functions of health and self-esteem against depression in older adults facing illness or bearevement. Psychology and Aging, 6, 352-360.

Neff, J., \& Hoppe, S. (1993). Race/ethnicity, acculturation and psychological distress: Fatalism and religiosity as cultural resources. Journal of Community Psychology, $21,3-20$

Neighbors, H. W., Jackson, J. S., Broman, C., \& Thompson, E. (1996). Racism and the mental health of African Americans: The role of self and system blame. Ethnicity and Disease, 6, 167-175.

Oxman, T., Freeman, D., \& Marnheimer, E. (1995). Lack of social participation or religious strength and comfort as risk factors for death after cardiac surgery in the elderly. Psychosomatic Medicine, 57, 5-15. 
Pargament, K. I., \& Brant, C. R. (1998). Religion and coping. In H. G. Koenig (Ed.), Handbook of religion and mental health (pp. 111-128). San Diego: Academic Press.

Pargament, K., \& Hahn, J. (1986). God and the just world: Causal and coping attributions to God in health situations. Journal for the Scientific Study of Religion, 25, 193-207.

Pargament, K., Kennell, J., Hathaway, W., Grevengoed, N., Newman, J., \& Jones, W. (1988). Religion and the problem-solving process: Three styles of coping. Journal for the Scientific Study of Religion, 27, 90-104.

Perlmuter, L. C., \& Monty, R. A. (1977). The importance of perceived control: Fact or fantasy? American Scientist, 65, 759-765.

Proudfoot, W., \& Shaver, P. (1976). Attribution theory and the psychology of religion. Journal for the Scientific Study of Religion, 14, 317-330.

Rambo, L. R. (1992). The psychology of conversion. In H. N. Malony, S. Southard, et al.), Handbook of religious conversion (pp. 159-177). Birmingham, AL: Religious Education Press.

Rambo, L. R. (1993). Understanding religious conversion. New Haven: Yale University Press.

Seybold, K. S., \& Hill, P. C. (2001). The role of religion and spirituality in mental and physical health. Current Directions in Psychological Science, 10, 21-24.

Skinner, E. A. (1996). A guide to constructs of control. Journal of Personality \& Social Psychology, 71, 549-570.

Spilka, B., Shaver, P., \& Kirkpatrick, L. A. (1985). A general attribution theory for the psychology of religion. Journal for the Scientific Study of Religion, 24, 1-20.

Taylor, R. J., Mattis, J., \& Chatters, L. M. (1999). Subjective religiosity among African Americans: A synthesis of findings from five national samples. Journal of Black Psychology, 25, 524-543.

Thompson, S. C., \& Collins, M. A. (1995). Applications of perceived control to cancer: An overview of theory and measurement. Journal of Psychosocial Oncology, 13, 11-26.

Thurnher, M. (1983). Turning points and developmental change: Subjective and "objective" assessments. American Journal of Orthopsychiatry, 53, 52-60.

Ullman, C. (1989). The transformed self: The psychology of religious conversion. New York: Plenum Press.

Wallis, C. (1996). Faith \& healing. Time, 58-64.

Wallace, K. A., \& Bergeman, C. S. (2002). Spirituality and religiosity in a sample of African American elders: A life story approach. Journal of Adult Development, 9, 141-154.

Weiss, R. S. (1994). Analysis of data. In Learning from strangers: The art and method of qualitative interview studies (pp. 151-182). New York: The Free Press.

Weisz, R., Jr., \& Stipek, D. J. (1982). Competence, contingency, and the development of perceived control. Human Development, 25, 250-281.

Wethington, E., Cooper, H., \& Holmes, C. (1997). Turning points in midlife. In I. H. Gotlib \& B. Wheaton (Eds.), Stress and adversity over the life course: Trajectories and turning points (pp. 215-231). Cambridge: Cambridge University Press. 
420 / FIORI, HAYS AND MEADOR

Wheaton, B., \& Gotlib, I. (1997). Trajectories and turning points over the life course: Concepts and themes. In I. H. Gotlib \& B. Wheaton (Eds.), Stress and adversity over the life course: Trajectories and turning points (pp. 1-25). Cambridge: Cambridge University Press.

Wong-McDonald, A., \& Gorsuch, R. L. (2000). Surrender to God: An additional coping style? Journal of Psychology and Theology, 28, 149-161.

\section{Direct reprint requests to:}

Judith C. Hays, RN, Ph.D.

Institute for Social Research, Room 5080

University of Michigan

P.O. Box 1248

426 Thompson St.

Ann Arbor, MI 48106-1248 